\title{
Who's Afraid of Transnational Legal Theory?: Dangers and Desiderata
}

\author{
Julie Dickson*
}

\begin{abstract}
The rise in both number and importance of various forms of intra-, inter-, supra- and trans-national legal phenomena presents distinctive challenges for legal philosophers seeking to explain and evaluate such phenomena in their theories of law. This article focuses on one facet of those challenges, namely their relevance for the methodology, or the philosophy, of transnational legal theory. Must we devise new, or, at least, significantly revised, legal philosophical methodologies in order successfully to explain and evaluate the character and distinctiveness of transnational legal phenomena? Or do we merely need to apply, and perhaps somewhat adapt, existing methodological approaches successfully deployed in general legal philosophy, to the particular case of transnational law? These are complex questions, and cannot be tackled in their entirety here. This article hence takes the approach of identifying and exploring some dangers to be overcome or avoided, and some desiderata that we should strive to attain, if our theories of law are to be sufficiently attuned to, and appropriately illuminating regarding, the domain of transnational law.
\end{abstract}

Keywords: Transnational Law; Legal Philosophy; Methodology; Jurisprudence

\section{INTRODUCTION}

Who's Afraid of Transnational Legal Theory? Arguably, no one. For, notwithstanding some ardent denunciations: 'The neglect of international law in modern analytic jurisprudence is nothing short of scandalous. Theoretically it is the issue of the hour ... ${ }^{1}$, the current jurisprudential scene seems rather to be a case of cometh the hour, cometh the many, various, and proliferating theoretical accounts of intra-,

\footnotetext{
* Associate Professor, Faculty of Law, University of Oxford and Fellow and Senior Law Tutor, Somerville College, Oxford, julie.dickson@law.ox.ac.uk This article is dedicated to my late uncle, lan Maxwell, whose encouragement early on in my life meant so much to me. I would like to thank Michael Giudice for his role in piquing and sustaining my interest in the puzzles of transnational legal theory. I am also grateful to the organisers of and participants in the University of Bristol Law School workshop on "'Doing Law beyond the State" Legal-Philosophical Challenges in International and Transnational Legal Research' www.bris.ac.uk/law/news/2014/404.html - held on 17-18 January 2014 at the University of Bristol Law School, for stimulating discussion of many of the ideas discussed here. The anonymous peer reviews I received from Transnational Legal Theory also helped me to clarify my stance on certain matters, as did the excellent advice and feedback from Richard Collins and Patrick Capps. The titular question refers, of course, to a kind of theoretical enterprise, and not to the journal of the same name!

$1 \mathrm{~J}$ Waldron, 'Hart and the Principles of Legality', in MH Kramer, C Grant, B Colburn and A Hatzistavrou, The Legacy of H.L.A. Hart: Legal, Political, and Moral Philosophy (Oxford University Press (hereafter 'OUP'), 2008).
} 
inter-, supra- and trans-national law. ${ }^{2}$ Admittedly, some of these accounts have emerged or been developed significantly since Jeremy Waldron's above censure. Other work in this area, however, is of longer standing, something which perhaps should prompt us to consider why it has been less widely read, debated, and absorbed than it deserves. ${ }^{3}$

Clearly, then, contemporary legal philosophers are not much afraid of transnational legal theory, ${ }^{4}$ and, given the growing importance of the issues it addresses, and my own interest in this field, ${ }^{5}$ it is not my intention to induce such trepidation here. However, I do want to identify and consider some dangers which might form traps for the unwary, and which hence must be avoided or overcome by legal philosophers seeking to engage in transnational legal theory. Moreover, and moving beyond the avoidance of relevant dangers, it is also vital for legal philosophers in this field to reflect upon and work towards certain valuable aims - or desiderata - as regards the kind of transnational legal theory they develop.

The 'dangers and desiderata' I have in mind are, we might say, 'methodological' in character. They concern certain challenges, and theoretical aims, relevant to how we ought to go about developing accounts of transnational legal phenomena, and to what the criteria of success of such enterprises might be. Some of the relevant issues arise particularly from the distinctive character of certain forms of intra-, inter-, supra- and trans-national law. Others are more plausibly viewed as methodological issues pertaining to legal philosophy generally, but which assume new forms or take on new aspects when considered in the context of the transnational.

\footnotetext{
${ }^{2}$ See eg D von Daniels, The Concept of Law from a Transnational Perspective (Ashgate, 2010); K Culver and M Giudice, Legality's Borders: An Essay in General Jurisprudence (OUP, 2010); K Culver and M Giudice, 'Making Old Questions New: Legality, Legal System, and State' in W Waluchow and S Sciaraffa (eds.), Philosophical Foundations of the Nature of Law (OUP, 2013); Amanda Perreau-Saussine, 'Immanuel Kant on International Law' in S Besson and J Tasioulas (eds.), The Philosophy of International Law (OUP, 2010); N Roughan, Authorities: Conflicts, Cooperation and Transnational Legal Theory (OUP, 2013); and, more generally, the essays in Besson and Tasioulas (eds.), The Philosophy of International Law (ibid) and the essays in J Dickson and P Eleftheriadis (eds), Philosophical Foundations of European Union Law (OUP, 2012).

${ }^{3}$ eg E Attwooll, The Tapestry of Law: Scotland, Legal Culture and Legal Theory (Kluwer, 1996); C Richmond, 'Preserving the Identity Crisis: Autonomy, System and Sovereignty in European Law', (1997) 16 Law and Philosophy 377; I Weyland, 'The Application of Kelsen's Theory of the Legal System to European Community Law - The Supremacy Puzzle Resolved' (2002) 21 Law and Philosophy 1; A Perreau-Saussine, 'Jurisprudence as a source of international law: Oppenheim as a case study' in M Craven, M Fitzmaurice and M Vogiatzi (eds), Time, History and International Law (Brill, 2006); A Perreau-Saussine, 'Three ways of writing a treatise on public international law: textbooks and the nature of customary international law' in A Perreau-Saussine \& J Murphy (eds.) The nature of customary law: philosophical, historical and legal perspectives (Cambridge University Press, 2007).

4 Throughout this article, I use the terms 'transnational law' and 'transnational legal theory' in a broad manner, ie as 'umbrella' terms encompassing the character, and theoretical understanding of, the several forms of non-state law mentioned above, ie intra-, inter-, supra- and trans-national law. This broad understanding of 'transnational legal theory' comports well with the use of that term in the title, and in indicating the ambit, of this journal: see Transnational Legal Theory (Hart Publishing, online ISSN: 2041-4013)'s inaugural editorial by Professor Craig Scott, available at: www.hartjournals.co.uk/tlt/tlt.pdf

${ }^{5}$ See, all by Julie Dickson: 'How Many Legal Systems? Some Puzzles Regarding the Identity Conditions of, and Relations Between, Legal Systems in the European Union' (2008) 2 Problema 9; 'Directives in European Union Legal Systems: Whose Norms Are They Anyway?' (2011) 17 European Law Journal 190; 'Towards a Theory of European Union Legal Systems' in Philosophical Foundations of European Union Law, (n 2).
} 
In this article, I identify and begin to explore the character of some of these dangers and desiderata. My work on the methodology of legal philosophy more generally is germane to this enterprise, and will be highlighted in the course of the discussion. ${ }^{6}$ Ultimately, of course, methodological dangers must be avoided or overcome, and desiderata must be attained by legal philosophers in the course of those substantive accounts of the character of law they develop. However, useful progress can be made by identifying and exploring various dangers and desiderata in a discussion such as this with a more 'methodological' focus: it can alert us to, and prompt a deeper understanding of, the character of transnational legal theory, and the manner in which we should engage in it.

The discussion is structured as follows. Section 2 identifies, and subjects to critical scrutiny, some dangers lurking within a two-pronged methodological claim often made by legal philosophers in theorizing transnational legality. With these dangers brought to light, section 3 then identifies and begins to develop my view of those desiderata which transnational legal theory should strive to attain. A brief conclusion indicates the territory covered, and emphasises once more the 'methodological orientation' which I advocate for those engaging in transnational legal theory.

\section{THE 'DUAL CLAIM’ AND ITS INHERENT DANGERS}

A recurring theme in transnational legal theory scholarship is the claim that the inter-, supra-, intra-, transnational legal phenomena which constitute the relevant subject-matter are significantly and importantly novel, distinctive and different from the forms of legality - legality associated with nation-states - which we have encountered to date. Moreover, this line of thought continues, what are variously referred to as 'traditional', 'state-based' or 'state-centric' jurisprudential theories, remain hopelessly hidebound to concepts and paradigms apposite specifically to understanding state law, and are hence incapable of adequately explaining or evaluating the new phenomena, and frequently neglect it altogether.

This two-pronged charge (which I will refer to hereafter as the 'dual claim'): that contemporary transnational legal phenomena is radically novel and very different from forms of legality encountered hitherto; and that 'traditional' legal theories are so state-bound in influence and outlook that they are incapable of adequately conceptualizing the 'new phenomena', is frequently, and, in my view, sometimes rather unreflectively, laid by theorists working in this area. Where this dual claim is made, it is chiefly used

\footnotetext{
${ }^{6}$ I have explored various facets of the methodology of legal philosophy in general in the following works, all by Julie Dickson: Evaluation and Legal Theory (Hart, 2001); 'Methodology in Jurisprudence: a critical survey' (2004) 10 Legal Theory 117; 'On Naturalizing Jurisprudence: Some Comments on Brian Leiter's View of What Jurisprudence Should Become' (2011) 30 Law and Philosophy 477; 'Law and Its Theory: a Question of Priorities' in RP George and J Keown (eds), Reason, Morality and Law: the Jurisprudence of John Finnis (OUP, 2013); 'Ours is a Broad Church: Indirectly Evaluative Legal Philosophy as a Facet of Jurisprudential Inquiry' (2015) 6 Jurisprudence (forthcoming).
} 
to construct a jumping-off point for the theorist's own alternative and innovative theory of law - an account which kicks over the traces of the traditional, state-based accounts, and heralds a new way of thinking about law which is capable of engaging with the 'new phenomena' of the transnational legal era. ${ }^{7}$

The dual claim identified above is important, and transnational legal theorists need carefully to consider and engage with the issues it raises. Trouble arises, however, when we skip too cursorily over the details of, and justifications for, arguments regarding the radically innovative character of the 'new legal phenomena' and the clear-cut inadequacy of theories of law to date as regards characterising and analysing such phenomena. Doing so would be a significant methodological mistake, and constitutes an important danger which transnational legal theory should strive to avoid. In the remainder of this section, I will critically examine each prong of the dual claim, in order to cast important doubts upon aspects of it, and to signal the dangers inherent in legal philosophers espousing exaggerated, vague and inadequately justified versions of it.

\section{(A) Scrutinising the Dual Claim Part I: Are Transnational Legal Phenomena Really So Novel?}

As was noted above, the first 'prong' of the dual claim is the view, oft-espoused by theorists working in this area, that transnational legal phenomena increasingly prevalent in our contemporary legal world, are significantly novel and distinctive, and differ markedly from the nation-state-based legal phenomena encountered hitherto. The schematic tale often told is that the terms of the 1648 Peace of Westphalia ushered in an era dominated by distinct and independent nation-states; an era which had the doctrine of state sovereignty - understood largely as a principle shielding states from external legal and political interference - as its keystone. However, from the mid-twentieth century onwards, the standard narrative continues, we have witnessed the inception and increasingly rapid development of a multiplicity of new forms of inter-, intra-, trans-, and supra-national legal regulation. This new phenomena differs so radically from the three centuries of Westphalian nation-state-law which preceded it, that it requires a radical

\footnotetext{
${ }^{7}$ In my view, the primary proponents of this approach are Michael Giudice and Keith Culver. Because of this, and also because, despite the criticisms I have of their work, it undoubtedly ranks amongst the best and most analytically rigorous in this area, I will have frequent recourse to Culver and Giudice's work for the purposes of illustration. For evidence that their work exhibits the features I ascribe to it, see Culver and Giudice, Legality's Borders: An Essay in General Jurisprudence (n 2), passim, but especially at xiii-xxvii, 22-5, 64-5, 72-4, 134-5, 161-5; K Culver and M Giudice, 'Not a System but an Order: An Inter-Institutional View of European Union Law' in Dickson and Eleftheriadis (eds), Philosophical Foundations of European Union Law (n 2), passim, but especially at 55, 60, 68; Culver and Giudice, 'Making Old Questions New: Legality, Legal System, and State' (n 2), passim, but especially at 281-5; 290-5. In my view, there are also manifestations of this approach in eg B Tamanaha, A General Jurisprudence of Law and Society (OUP, 2001), passim, but especially chapters 6-8; R Cotterrell, 'Transnational Communities and the Concept of Law', (2008) 21 Ratio Juris 1; P Capps, 'International Legal Positivism and Modern Natural Law', in J Kammerhofer and J D'Aspremont (eds.), International Legal Positivism in a Post-Modern World (Cambridge University Press (hereafter 'CUP'), 2014). The constraints of space do not allow me to explore the works of these latter theorists here, and, for present purposes, Culver and Giudice can be taken as the main proponents of this approach, as detailed in the specific pages of the specific works cited above.
} 
departure from existing ideas, understandings, and concepts featuring in 'traditional' state-based legal philosophy. ${ }^{8}$

As with most ideas in intellectual life, there is no doubt some truth to this schematic tale, and I do not seek to deny that here. But some truth is not the whole truth, and in the exaggerated and overly simplistic form in which it sometimes appears, this narrative conceals important continuities between allegedly very different legal phenomena. Furthermore, it generates an intellectually unhealthy smokescreen around the complexity and diversity exhibited by various important legal phenomena with which we are familiar, and which have been considered carefully and in-depth in some theoretical accounts of law.

To lift the fog, we need to interrogate further the 'Westphalian narrative' outlined above, in order to separate myth from reality within it. This narrative appears to engender in the work of some legal theorists the view that during the period allegedly preceding the current transnational era, wherein independent nation-states co-existed under conditions of Westphalian sovereignty, that each such nation-state had a single legal system claiming comprehensiveness of jurisdiction throughout the clearly delineated territory of that state. This 'one legal system per nation-state' model connotes the idea of each nation-state having its own distinctive set of law-creating, law-applying and law-enforcement institutions, and its own distinctive law-identification practices. On this view, each independent nation-state, and its corresponding legal order, does not acknowledge or accept any claims to authority issuing from legal institutions outwith that nation-state, and does not exhibit within that state significant legal pluralism in the form of, for example, a multiplicity of sets of institutions creating and applying legal norms, or a plurality of different and potentially rival law-identification practices. ${ }^{9}$ This 'single legal order per independent nation-state' situation is claimed, of course, to stand in stark contrast to the current transnational legal era, wherein the much-discussed, multiple, and variform types of legal and constitutional pluralism are the order of the day. Such pluralism comes in many forms and encompasses a range of ideas, including that our legal world is now awash with multiple and rival sets of institutions, law-identification and law-application practices, each simultaneously mounting different and potentially conflicting claims to authority, and to determine our normative position under law. ${ }^{10}$

\footnotetext{
${ }^{8}$ For discussion of this narrative in various contexts, see Culver and Giudice, Legality's Borders (n 2), especially the Introduction, and chapters 2, 4 and 5; N Walker, 'Beyond boundary disputes and basic grids: Mapping the global disorder of normative orders' (2008) 6 International Journal of Constitutional Law 373; P. Zumbansen, 'Comparative, global and transnational constitutionalism: The emergence of a transnational legal-pluralist order' (2012) 1 Global Constitutionalism 16-52; A Buchanan, 'Rawls's Law of Peoples: Rules for a Vanished Westphalian World' (2000) 110 Ethics 697.

${ }^{9}$ See Culver and Giudice, Legality's Borders (n 2), particularly at xxiv, 164; Culver and Giudice, 'Making Old Questions New: Legality, Legal System, and State' (n 2), particularly at 290-5.

${ }^{10} \mathrm{Nb}$ given the focus on this article, I cannot discuss here the many different forms and types of pluralism featuring in the academic literature in this area, and cite merely a few examples of works featuring the kinds of claims I have in mind: see eg
} 
The trouble with this characterisation of the differences between the Westphalian era and contemporary transnational legality is that it employs unhelpfully polarizing contrasts, and, as a result, presents a distorted and overly simplistic picture of state-based legal phenomena, and an exaggerated and inaccurate view of exactly how, and in what ways, contemporary transnational legal phenomena is distinctive and novel.

For instance: contra the above narrative, we do not have far to look in order to find counter-examples to the 'one legal system per independent nation-state' model outlined above, some of which existed or even commenced during the height of the Westphalian era, and continued throughout that era, in some cases, right up until the present day. My own state - the United Kingdom - and my own nation within that state - Scotland - furnishes us with a prime example. Since its inception, what was to become the United Kingdom of Great Britain and Northern Ireland has been a multi-legal system state, the several legal systems ${ }^{11}$ of which have - at different times and in different forms - accepted the authority of institutions plausibly understood as being outwith the legal system in question. When Scotland and England agreed the terms of the 1707 Treaty of Union, and then each nation enacted their own Acts of Union based thereon, the continuing existence of a distinct Scottish legal system, was constitutionally guaranteed. Moreover, the relevant guarantees, given in one of the key founding documents of the emerging new state, included an assurance that certain features and institutions of the Scottish legal system would remain 'in all time coming. ${ }^{\prime 2}$ This being so, the United Kingdom has always had multiple co-existing and interacting legal systems, a state of affairs explicitly recognised by the UK's Constitutional Reform Act 2005, in its declaration that:

'Nothing in this Part is to affect the distinctions between the separate legal systems of the parts of the United Kingdom. ${ }^{13}$

As a consequence, there is and always has been considerable legal institutional complexity and pluralism within the United Kingdom. On the law-creating front, the UK has always had legislative institutions which are shared by more than one of its legal systems, particularly the Westminster Parliament, which is not the legislature uniquely of any one of the UK's legal systems. On the judicial front, the UK has always had co-existing and interacting authoritative legal orders, with multiple sets of judicial

Culver and Giudice, Legality's Borders (n 2), xvii-xxiii, 65-78, 148-171; N MacCormick, 'Juridical Pluralism and the Risk of Constitutional Conflict' in Questioning Sovereignty (n 3); N Walker, 'The Idea of Constitutional Pluralism' (2002) 65 MLR 317; M Kumm, 'The Moral Point of Constitutional Pluralism' in Dickson and Eleftheriadis (eds.), Philosophical Foundations of European Union Law (n 2).

11 The UK currently has three legal systems: the legal system of England and Wales; the legal system of Scotland; and the legal system of Northern Ireland.

12 See the Articles of Union, passim, but especially Article XIX, available at http://www.parliament.uk/documents/heritage/articlesofunion.pdf

${ }^{13}$ Constitutional Reform Act 2005 s 41 (1). 
and law-applying institutions, claiming at least at times to adhere to different, and rival, law-identification practices. For example, there has never been a right of appeal in criminal cases from the Scottish High Court of Justiciary - Scotland's highest criminal court - to the House of Lords, and now Supreme Court, although such an appeal can lie from the Scottish Court of Session in civil cases. ${ }^{14}$ Even in such civil cases, however, by strong and long-standing convention, at least one, and more usually two, of the Scottish Justices of the Supreme Court sit on the judicial panel, and those Justices usually (though not invariably) write the leading judgements. ${ }^{15}$ Moreover, the Constitutional Reform Act 2005 indicates that, in civil appeals from the Court of Session, the Supreme Court's judgement is to be regarded as a decision of a Scottish court (and that, correspondingly, in the case of appeals from the England and Wales legal system, or from the Northern Ireland legal system, that a decision of the Supreme Court is to be regarded as a decision of a court of that part of the United Kingdom). ${ }^{16}$

In addition to these interweaving intricacies of institutional pluralism and overlap, the distinct legal systems co-existing within the United Kingdom have sometimes claimed that they each endorse somewhat different, and potentially rival, law-identification practices, and espouse different understandings of certain constitutional principles, and of the role of various branches of government in securing them.

An example of this can be found in cases brought in the Scottish courts on the constitutional status and justiciability of the Treaty of Union. In various of these cases, in which there was an attempt to use certain articles of the Treaty of Union to found judicial review of primary UK legislation, Scottish courts, and Scottish judges, signalled their view that the Scottish legal system has a different understanding of the doctrine of the Sovereignty of Parliament (ie that it is not a proper part of the Scottish legal system), and a different understanding of law-identification practices, as compared with other legal orders in the UK, especially the legal system of England and Wales.

For instance, in MacCormick v Lord Advocate, an attempt was made to challenge, and potentially judicially review, the Royal Titles Act 1953 on the grounds that some of that which it allegedly authorised - including the styling of the current monarch as 'Elizabeth the Second of the United Kingdom of Great Britain' - was contrary to the Articles - particularly Article 1 - of the Treaty of Union 1707 (there having been no 'Elizabeth I' of Scotland, and indeed no United Kingdom for there to have been an 'Elizabeth I' of either, prior to the 1707 Union). In his leading judgement, Lord Cooper, the then Lord President of the Court of Session, declared (albeit obiter dicta as regards the decision on the facts of the instant case) that:

\footnotetext{
${ }^{14}$ For a discussion of the current arrangements, and their historical origins, see $\mathrm{N}$ Walker, 'Final Appellate Jurisdiction in the Scottish Legal System', a report prepared at the request of the Scottish Government, and available at: http://www.scotland.gov.uk/Publications/2010/01/19154813/0, especially chapter 3.

${ }^{15}$ For discussion, see Walker, ibid, and at Appendix IV.

${ }^{16}$ Constitutional Reform Act 2005 s 41 (2).
} 
The principle of the unlimited sovereignty of Parliament is a distinctively English principle which has no counterpart in Scottish constitutional law. It derives its origin from Coke and Blackstone, and was widely popularised during the nineteenth century by Bagehot and Dicey, the latter having stated the doctrine in its classic form in his Law of the Constitution. Considering that the Union legislation extinguished the Parliaments of Scotland and England and replaced them by a new Parliament, I have difficulty in seeing why it should have been supposed that the new Parliament of Great Britain must inherit all the peculiar characteristics of the English Parliament but none of the Scottish Parliament, as if all that happened in 1707 was that Scottish representatives were admitted to the Parliament of England. That is not what was done. ${ }^{17}$

Later in this same judgement, Lord Cooper also indicated that, were certain fundamental legal provisions of the Treaty of Union to be breached by an Act of the Westminster Parliament or by some other governmental action, then it was not out inconceivable that the act in question could be the subject of constitutional vires review on the grounds of breach of fundamental law, and justiciable in the Scottish courts. Similar views, referring approvingly to Lord Cooper's above remarks, have been expressed by Scottish judges in other 'attempted constitutional review' Scottish case law, eg by Lord Keith in Gibson v Lord Advocate. ${ }^{18}$ Moreover, in Scottish legal and academic circles, such claims regarding the different, and potentially conflicting, law-identification practices of the distinct legal systems co-existing within the UK, have been the subject of academic analysis, perhaps most notably in jurisprudential terms by Neil MacCormick who, in his article, 'Does the United Kingdom Have a Constitution? Reflections on MacCormick v. Lord Advocate' ${ }^{19}$ claims that the Scottish courts espouse a significantly different view of the rule of recognition as it determines the relative status of Acts of the UK Parliament and the Articles of the Treaty of Union, than is held by the courts in England and Wales:

... the Scottish courts' view of the ultimate rule of recognition appears to be that "Whatever the Queen in Parliament enacts, unless in derogation from the justiciable limits set by the Articles of Union, is law'.20

The UK is hence a prime example of a single state which is, and always has been, including at the height of the Westphalian era, replete with a plurality of distinct yet interacting and overlapping sets of legal institutions, multiple loci of legal and constitutional authority, and differing and potentially rival understandings of law-identification practices, resulting from the differing claims made within, and the interweaving interactions between, its several legal systems.

\footnotetext{
${ }^{17}$ MacCormick v Lord Advocate 1953 SC 396, per Lord Cooper.

181975 SC 136. Such issues continue to emerge and re-emerge in more recent times, see eg Pringle, Petitioner 1991 SLT 330; Murray v Rogers 1992 SLT 221; Fraser v MacCorquodale 1992 SLT 229; Lord Gray's Motion 2000 SC (HL) 46.

19 (1978) 29 Northern Ireland Legal Quarterly 1.

20 Ibid at 11. See also the discussions of these issues in N Walker and CMG Himsworth, 'The Poll Tax and Fundamental Law' (1991) 45 Juridical Review 45; DJ Edwards, 'The Treaty of Union: more hints of constitutionalism' (1992) 12 Legal Studies 34; Lord Hope of Craighead, 'Is the Rule of Law now the Sovereign Principle?' in R Rawlings, P Leyland and A Young (eds.), Sovereignty and the Law: Domestic, European and International Perspectives (OUP, 2013).
} 
Moreover, the examples given above are not unique, and may not be particularly unusual either. A further instance of legality - this time extra-state legality - which confounds the simplicity of the Westphalian narrative can be found in practices of some independent, and clearly accepted as independent, states which were former British colonies. In the case of several such independent states, they retained for many decades, and, in some cases still retain, the (British) Judicial Committee of the Privy Council as their highest court of appeal in certain cases. Historically speaking, post-independence Singapore, Malaysia, and New Zealand adopted this practice for some time - in New Zealand's case, right up until 2003. Several independent countries, including Jamaica, The Bahamas, and Antigua and Barbuda, still do so today. ${ }^{21}$

Post-independence, these states, for a variety of different reasons did, and in some cases do, recognise and accept the authority of an extra-state judicial institution as the highest court of appeal in a range of cases. Accordingly, they not do meet the conditions of Westphalian sovereignty as it is customarily understood. While such circumstances stand in need of explanation and analysis, what is not in doubt is that they exist, and have existed, evincing the fact that acknowledging and accepting as authoritative certain extra-state legal institutions is not a never-before-seen phenomenon which has emerged only with recent developments in transnational legal phenomena, such as the supra-national institutions and legality of the contemporary European Union.

The first 'prong' of the dual claim - the contention that contemporary transnational legal phenomena is radically novel and very different from forms of state-based legality encountered hitherto - is not entirely wide of the mark, and may have some truth to it, especially in terms of the ubiquity and pace of development of different kinds of transnational legality. However, in its overly simplistic and unexamined form, this first aspect of the dual claim does significantly distort the character of, and exaggerate the differences between, certain forms of legality. The 'new phenomena' of the current transnational era is not all so new as is claimed in the work of some legal theorists, and is not such radical news either, in the sense that many scholars have been aware of, and have sought to analyse and explain instances of such phenomena in their work in legal philosophy.

\section{(B) Scrutinising the Dual Claim Part II: Is Existing Legal Philosophy Really Guilty As Charged?}

The final point mentioned above paves the way for an examination of the second 'prong' of the dual claim. As will be recalled, the contention here is that 'traditional' jurisprudential theories are so state-bound or state-centric in influence and outlook that they remain hopelessly hidebound to concepts and paradigms

\footnotetext{
${ }^{21}$ See https://www.jcpc.uk/about/role-of-the-jcpc.html
} 
apposite only to understanding state law, and are hence incapable of explaining and evaluating, and frequently neglect altogether, the 'new phenomena' of the transnational legal era.

Unfortunately, this second aspect of the dual claim is sometimes rendered in somewhat vague and slippery terms by legal philosophers working in this area. For example, in Keith Culver and Michael Giudice's work, several different versions of this part of the dual claim are espoused at different points, and there is frequent and apparently unnoticed slippage between them. As a result, an important initial difficulty in evaluating whether existing legal philosophy is 'guilty as charged' under this second prong of the dual claim, is in ascertaining exactly what it is charged with. For instance, is the charge:

(i) simply that 'traditional' or state-centric legal theories did not (and do not), de facto, focus on transnational legal arrangements, and that this bare fact alone is sufficient to condemn those theories as inadequate even at their time of writing, and a fortiori, incapable of explaining and evaluating contemporary transnational legal phenomena? ${ }^{22}$

(ii) that 'traditional' legal theories did not (and do not) grant adequate importance to transnational legal arrangements that already existed at the time those theories were developed, and/or were wrong to take other forms of legality, eg state law, as their central focus? ${ }^{23}$

(iii) that 'traditional' legal theories are not only guilty of the charges laid in (i) and/or (ii) above, but that even after considered reflection upon the various forms of transnational legality which now exist (and which, in some cases, have come into existence since the time those 'traditional' theories were written), those theories still remain incapable of accurately characterising, or of offering illuminating insights regarding, transnational law? ${ }^{24}$

(iv) that 'traditional' legal theories are not only guilty of the charges laid in (i) andor (ii) above, but that even after considered reflection upon the various forms of transnational legality which now exist, those theories will (inevitably? if so, why?) still fail to grant adequate importance to, and fail appropriately to focus on, transnational law ${ }^{25}$

\footnotetext{
22 This version of the charge can be found in Culver and Giudice, Legality's Borders (n 2) at 22, and in Culver and Giudice, 'Not a System but an Order: An Inter-Institutional View of European Union Law' in Dickson and Eleftheriadis (eds), Philosophical Foundations of European Union Law (n 2), at 58-9.

${ }^{23}$ This version of the charge appears in Legality's Borders (n 2) at xxiii, 62-5, 134-5, in 'Not a System but an Order: An InterInstitutional View of European Union Law' in Dickson and Eleftheriadis (eds), Philosophical Foundations of European Union Law (n 2), at 58-9, and in Culver and Giudice, 'Making Old Questions New: Legality, Legal System, and State' (n 2), at 279-80.

${ }^{24}$ This version of the charge can be found in Legality's Borders ( $\mathrm{n} 2$ ) at xvi, 74, 160-9, in 'Not a System but an Order: An InterInstitutional View of European Union Law' in Philosophical Foundations of European Union Law (n 2), 60-1, 68, 74-5, and in 'Making Old Questions New: Legality, Legal System, and State' (n 2), at 279-80, 283-4, 292-5.

${ }^{25}$ This version of the charge appears in Culver and Giudice, 'Not a System but an Order: An Inter-Institutional View of European Union Law' in Philosophical Foundations of European Union Law (n 2), at 60, and in 'Making Old Questions New: Legality, Legal System, and State' (n 2), at 283-4, 292-5. Some legal philosophers, eg Jeremy Waldron, appear to view existing jurisprudential scholarship as guilty of all four of these charges, and to see very little hope that this might change in future, at least in the case
} 
As there is such difficulty in ascertaining the precise terms of the charge levelled by the second prong of the dual claim, evaluating whether it is accurate and well-grounded is extremely problematic. This being so, I will restrict myself to offering some brief remarks regarding variants (i) to (iv) above. ${ }^{26}$

Re. (i) although we must, as I argued in section $2 \mathrm{~A}$, be wary of over-stating and of merely assuming the novelty and distinctiveness of contemporary transnational legal phenomena, we should also take adequate notice of the fact that some contemporary instances of such phenomena, and some recent developments in the character of such phenomena genuinely are new, and have come into existence and/or been significantly developed since the time of writing of some of the 'traditional' theories of law oft-castigated for failing adequately to address them. For example, some excoriating criticism has been aimed at HLA Hart for his failure to offer a sufficiently nuanced or in-depth analysis of international law in The Concept of Law. ${ }^{27}$ To read some of this sort of criticism, one might be forgiven for thinking that The Concept of Law was published in recent years, years in which developments in public international law, in international commercial law, in international human rights law, and in the character and reach of the supra-national law of the European Union, were apace and clearly deserving of sustained analysis in a work purporting to offer a general account of law's nature. But it is more than half a century since Hart published The Concept of Law, and several more years still since he was working on and developing the ideas central to it. The European Union, for example, barely existed when Hart developed the central ideas of The Concept of Law, and would not go on to develop the powerful and wide-ranging supra-national legality for which it is now (in?)famous for several decades after the book's publication. Ignorance of, and failure adequately to engage with, legal phenomena of vital importance and significance at the time of writing of the theory in question are surely relevant failings in a legal philosopher, but the absence of jurisprudential clairvoyance surely is not.

Regarding (ii) above, in addition to the points just made re. (i), which are relevant here as well, we might also profitably remind ourselves that all theories of law are developed at a particular time, and in a particular intellectual, historical and social context, and that this influences the questions they ask and answers they offer. Moreover, and as I have argued in-depth elsewhere, given the evident complexity of law, all legal philosophers do, and must, select merely a sub-set of law's features to focus on, and a subset of all possible questions that might be asked about law. A given theory of law hence cannot be condemned merely for choosing to focus on one group of puzzles or features of law rather than another

of those Waldron refers to as 'Hart's followers', see J Waldron, 'International Law: 'A Relatively Small and Unimportant' Part of Jurisprudence?', in L Duarte d'Almeida, J Edwards and A Dolcetti (eds.), Reading HLA Hart's 'The Concept of Law' (Hart, 2013).

${ }^{26} \mathrm{nb}$ I am not claiming that (i) to (iv) above are either mutually exclusive or jointly exhaustive of the possibilities in this regard.

27 See eg I Brownlie, The Rule of Law in International Affairs: International Law at the Fiftieth Anniversary of the United Nations (Hague Academy of International Law Monographs) (Kluwer, 2012), at 3-7; Waldron, 'International Law: 'A Relatively Small and Unimportant' Part of Jurisprudence?' (n 25). 
such group, for it has no choice but to do so, and it is a virtue, as well as an inevitability, of our theories of law that they do so. ${ }^{28}$

Re. (iii) it is vital, of course, to distinguish between the claim that a given theory de facto did not focus upon certain phenomena, and the claim that, even had it done so, or chose to do so now, it would be incapable of characterising and explaining it. However, all too often complainants in this regard - including on occasion Culver and Giudice - appear to slide between these two charges, and to take a theory's failure de facto to focus on non-state legality as evidence that the theory in question could not, even on considered reflection of such phenomena, successfully characterise and explain it. ${ }^{29}$

Many of the points just mentioned in relation to (iii) are relevant also to (iv). The fact that certain legal philosophers and certain theories of law, shaped as they were by the intellectual time and place they arose in, did not in the past give sufficient focus to transnational law, is not in itself evidence that, even after considered reflection upon the various forms of transnational legality which now exist, those legal philosophers and the theories they espouse will still fail to grant adequate importance to such legality. Indeed, and as the existence of this journal, this special issue within it, and many of the works discussed in this article indicate, contemporary legal philosophers seem more than willing to turn their attention and their theoretical understandings to intra-, inter-, supra- and trans-national legal phenomena.

\section{(C) Avoiding the Dangers of the Dual Claim: What Is the 'Pay-Off' and Why Does It Matter?}

What lessons should we learn from the discussion so far? Why does it matter that we strive to avoid the dangers identified and explored above? In my view, the central messages to take away are:

(i) that it is important to develop an analytically rigorous and precise diagnosis of the problems legal philosophy faces in its attempts to address the character of, and puzzles generated by, transnational legal phenomena. Only then, with an accurate and in-depth understanding of the relevant difficulties, will we be in a position to develop our theories of law in a manner apposite to those puzzles. Inadequately justified and over-hasty endorsements of the dual claim are not sufficient and constitute dangers to be avoided (ii) that illuminating transnational legal theory is best served by theorists attempting to chart a nuanced and temperate way between two pernicious exaggerations: that everything is new under the sun as regards the novelty of transnational legal phenomena and that existing theoretical understandings are hence of little or no use in explaining and evaluating it; or that nothing is new under the sun as regards transnational legal phenomena, and philosophy of law can carry on in a 'business as usual' manner, taking the puzzles of

\footnotetext{
${ }^{28}$ See J. Dickson, 'The Central Questions of Legal Philosophy' (2003) 56 Current Legal Problems 63.

${ }^{29}$ See eg Culver and Giudice, 'Not a System but an Order: An Inter-Institutional View of European Union Law' (n 25), 60-1; Culver and Giudice, 'Making Old Questions New: Legality, Legal System, and State' (n2), at 283-4.
} 
the transnational effortlessly in its stride without serious reconsideration of, and, if necessary, significant revision of, current ways of conceptualizing law's character.

If we fail to analyse in sufficient detail or depth the degree of novelty of the 'new phenomena', and if we are not able to precisely pinpoint or adequately justify the alleged incapacity of existing theories of law to explain that phenomena, then we are in considerable danger of 'throwing the baby out with the bathwater', in the form of over-hastily ditching existing concepts and understandings which may be of considerable use in theorising the transnational. This danger is exacerbated by the fact that, 'Out with the old and in as quickly as possible with the new!' is a rallying cry of our intellectual time, and those answering its call with brand spanking new alternative theories and concepts are often 'rewarded' in terms of the incentive-structures of contemporary academia. Of course, appropriate responsiveness to changing phenomena, and apt revision, development and innovation in our accounts of law are vital to their ongoing accuracy and richness, and to the intellectual health of legal philosophy as a whole. Sometimes, however, it is enormously important not to obscure today the light emanating from what we knew yesterday, and not to reject too hastily existing concepts and understandings in our zeal for the new.

\section{SOME DESIDERATA CONSIDERED:}

\section{SELF-UNDERSTANDINGS, STAGED INQUIRY AND AMELIORATIVE AIMS}

So much for the dangers. On a more positive note, we can draw the present discussion towards its close by considering some desiderata which transnational legal theory should aim to attain. In previous, present and planned future work on the methodology of legal philosophy generally, I have argued in favour of an approach to legal philosophy that I now refer to as 'Indirectly Evaluative Legal Philosophy.' ${ }^{30}$ In particular, in a recent article, I have characterised this approach as follows. Indirectly Evaluative Legal Philosophy (IELP) seeks to:

(i) identify and explain significant, important and illuminating aspects of the nature of law, and consider what it is for law to have a nature, and how truths about its nature are to be ascertained

(ii) understand and be sensitive to the ways in which the questions of legal philosophy arise in and change over time

(iii) adequately account for, and explain the relevance of, the self-understandings - in terms of the concept of law and related concepts - of those who are subject to, create, and administer the law

(iv) adopt an approach which resists premature and/or immoderate veneration of law, by proceeding from what we might call an 'attitude of due wariness' regarding law, and by postponing,

\footnotetext{
${ }^{30}$ See those works referred to in note 6 above. I am also working on a new book on this topic, working title, Elucidating Law: The Philosophy of Legal Philosophy, currently under contract with Oxford University Press.
} 
and, in a certain sense, limiting, the role of moral evaluation in our theories of law, until certain questions have been addressed

(v) facilitate and engender moral and other evaluation, criticism and reform of the law, tasks which are a vital part of legal philosophy

Broadly speaking, I believe that these tenets, first conceived in my work as constituting the correct methodological approach to legal philosophy generally, also hold in respect of the particular case of legal philosophy addressing the puzzles and challenges of transnational legality. ${ }^{31}$ For present purposes, however, I wish to offer some remarks on two of these tenets in particular, namely (iii) and (iv) above, in order to indicate more specifically the ways in which they might constructively shape transnational legal theory.

Tenet (iii) is a vital element in Indirectly Evaluative Legal Philosophy. ${ }^{32}$ It marks a commitment to the view that a large part of the task of legal philosophy is to advance our understanding of ourselves by illuminating various inter-related concepts which those administering and living under law already use in characterizing law, and their experience of it. This is important because when legal philosophers attempt to identify and elucidate aspects of the concept of law, they are attempting to explain a concept which is already used by users of that concept to understand themselves and their lives in terms of law. Those in societies governed by law think and speak of issues such as who gets to make law, whether they are the correct group to do so, what input others should have as regards the law-making process, and whether the law so made is just, fair, and offers appropriate solutions to difficult social problems. They consider and contrast what law requires with what morality, family obligations or religion require, and are familiar with dilemmas created when such requirements come into conflict. Those living under law have a sense of its mandatory character, of the consequences of breaking it, and of its potential for abuse, particularly by those whose task it is to create and administer it. As a consequence, legal philosophy is constrained in the character of the explanations it gives: it must seek to elucidate law in a way which does adequate justice to how it is already understood, and is understood to feature in, the lives of those who create, administer, and are subject to it.

Of course, it is also vital to appreciate that doing adequate justice to the existing self-understandings in terms of law of those living under and administering it does not mean engaging in some kind of jurisprudential 'vox-pop' exercise and merely surveying the views of all those living under and

\footnotetext{
${ }^{31}$ I discuss each of these in more depth in my forthcoming article: 'Ours is a Broad Church: Indirectly Evaluative Legal Philosophy as a Facet of Jurisprudential Inquiry' (n 6), section 3.

${ }^{32}$ Although it is not unique to it.
} 
administering law. As I have tried to argue in previous discussions of jurisprudential methodology, ${ }^{33}$ legal theory is not a kind of market research or dictation exercise wherein the legal theorist merely passively records wholesale the self-understandings of those living under law. Rather, the theorist herself has to be able to discriminate between and make evaluative judgments about participants' self-understandings in order to pick out which are most relevant in understanding law's important and significant features. Some self-understandings of the participants may be confused, mistaken, insufficiently focussed or vague. Moreover, some self-understandings will be more important and significant than others in explaining the concept of law. All of this requires the legal theorist not merely to record and reproduce but to evaluate and make judgments as regards the self-understandings of participants in constructing theories of law having contemporary interest and relevance. All this said, however, there remains a core and unshirkable responsibility incumbent upon legal philosophers to do adequate justice to, and not to ride roughshod over, participants'self-understandings, in develop their theories of law.

As I argued in section 2C above, one positive benefit or 'pay-off' of avoiding the dangers inherent in the dual claim, is that legal philosophers may be less likely to 'throw the baby out with the bathwater', in the form of over-hastily ditching concepts which might remain extremely useful in understanding aspects of transnational legality. In my view, Keith Culver and Michael Giudice fall foul of this danger in eschewing the concept of a legal system, which they view as a feature of 'traditional' state-centric theories of law, and as inapposite to understanding transnational legality. In their alternative 'inter-institutional' theory of law, ${ }^{34}$ legal phenomena are not to be understood in terms of discrete legal systems and the relations of those systems with the norms of other legal and non-legal normative systems. Rather, 'legality is shorn from officials, states, and geography'35 and is understood instead in terms of various state, intra-state, trans-state, supra-state and super-state legal institutions and norms interacting and engaging in 'mutual reference of varying intensity' ${ }^{36}$ and appearing in individuals' lives as 'upwellings of normative force, ${ }^{\prime 37}$ 'clustered around particular kinds of life events. ${ }^{38}$ On this account, the idea of those institutions and norms having a 'home' in particular legal systems is viewed as unimportant. ${ }^{39}$ Accordingly, they contend, '...it

\footnotetext{
${ }^{33}$ See, in particular, Dickson, 'Methodology in Jurisprudence: a critical survey', (n 6) especially in sections IIB and IIC, and Dickson, 'On Naturalizing Jurisprudence: Some Comments on Brian Leiter's View of What Jurisprudence Should Become' (n 6), at 493-7. For fuller discussion of the role of evaluative judgments in legal philosophy, see Dickson, Evaluation and Legal Theory (n 6), passim.

${ }^{34}$ Culver and Giudice, Legality's Borders (n 2), chs 4 and 5.

35 ibid 165.

36 ibid 112.

37 ibid 105.

38 ibid.

39 ibid 161-164.
} 
becomes increasingly less clear what meta-theoretical value is to be gained by holding onto the idea of legal system' and '...talk of separate legal systems only seems more and more distracting. ${ }^{\prime 40}$

Tenet (iii) of Indirectly Evaluative Legal Philosophy further bolsters the point about not throwing the baby out with the bathwater, in reminding us of the need to do adequate justice in our theories of law to those self-understandings in terms of law-related concepts, including the concept of a legal system, already espoused by those living under and administering law. In ditching the concept of a legal system, and offering a radically revisionist account of law in which it is deemed unimportant, Culver and Giudice fail adequately to account for and explain the important role which the concept of a legal system continues to play in the self-understandings of legal officials, legal institutions and citizens living under law.

As I have argued elsewhere ${ }^{41}$ not only do we employ the concept of a legal system to understand ourselves and aspects of our social world, but we do so in order to draw distinctions which are of importance and which matter to us, such as where 'our own' legal system ends and another begins. For example, the Scottish Government espouses the view that, '...the Scottish legal system has a long history, dating back to the medieval era. Its integrity and independence were acknowledged in the 1707 Act of Union...'42 Those responsible for administering law in Scotland clearly view Scots law as 'proudly independent', 'a cornerstone of Scottish life for centuries, ${ }^{43}$ and value it for being so, and for being distinctive, and distinguishable from other legal systems of the UK in terms of its historical roots, legal sources and institutional structure. ${ }^{44}$ An appreciation of Scottish culture, including Scottish legal, political and academic culture, readily reveals that such views concerning the existence and distinctive character of the Scottish legal system are a distillation of themes which echo down loudly through the media, political debate, legal academic thinking and teaching in law schools in Scotland, and which have done so for many years, not merely in the post-devolution era. ${ }^{45}$

\footnotetext{
40 ibid 74. For further claims of this kind demoting or eschewing the concept of a legal system, see Legality's Borders (ibid) xvi, 64-7, 161-9, and 'Not a System but an Order: An Inter-Institutional View of European Union Law' (n 25), particularly at 55, 75-6. ${ }^{41}$ See Dickson, 'Towards a Theory of European Union Legal Systems' in Philosophical Foundations of European Union Law, (n 2). 42 'Legal System' factsheet (2004) produced by the Scottish Government, available online: http://www.scotland.gov.uk/Resource/Doc/925/0000078.pdf p2.

43 ibid p1.

44 ibid passim.

45 see eg 'MPs warn UK reform must protect Scottish legal tradition', Edinburgh Evening News, online edition, 10 ${ }^{\text {th }}$ Feb 2004, http://edinburghnews.scotsman.com/uksupremecourt/MPs-warn-UK-reform-must.2502230.jp; 'Scotland is proud of, and jealously guards, its separate legal system', from Opinion piece, 'Fighting Fraud' in The Herald newspaper, online edition Feb $20^{\text {th }}$ 2009, http://www.theherald.co.uk/features/editorial/display.var.2487857.0.fighting fraud.php; the existence and proceedings of The Stair Society, instituted in 1934 to encourage the study and to advance the knowledge of the history of Scots law, http://www.stairsociety.org/home.htm. Legal and academic discourse on the topic is voluminous: for but a tiny sample, see the litigation and academic commentary mentioned in notes 14 to 20 above, and also HL MacQueen (ed), Scots Law into the $21^{\text {st }}$ Century: Essays in Honour of WA Wilson (W Green, 1996), Attwooll, The Tapestry of Law: Scotland, Legal Culture and Legal Theory (n 3); P Maharg, 'Imagined Communities, Imaginary Conversations: Failure and the Construction of Legal Identities' and
} 
Legal systems can clearly become the focus of attitudes of identification and attachment (as well as of alienation and disaffection). Those administering and living under law can, and, as the Scottish example indicates, frequently do, come to hold such attitudes of attachment to, identification with and even pride in their own law. In order to be able to say which law is 'their law' and to begin identifying its distinctive characteristics they need to, and do, make use of the concept of a legal system. This being so, the concept of a legal system is not merely something that we do happen to have recourse to in navigating our way around our societies and their law, it is a concept used to draw distinctions which are of vital importance to us in terms of the way we think about those societies, their boundaries, distinctiveness, our relation to them, and the values to which they aspire.

To give another example: the Court of Justice of the European Union has had strong and consistent recourse to the concept of a legal system in developing the supra-national and constitutional character of EU law. In Costa v. ENEL the doctrine of the supremacy of EU law is justified by the Court on the grounds that the EU 'has created its own legal system.' ${ }^{\prime 6}$ More recently, in Kadi and Al Barakaat $v$ Council, robust judicial review within the EU itself, even of EU measures giving effect to a UN security council resolution, is justified by the Court on the basis that, 'an international agreement cannot affect ... the autonomy of the Community legal system, observance of which is ensured by the Court... ${ }^{47}$ As these examples indicate, those administering and subject to the law continue to use the concept of a legal system, and use that concept in ways which are important and significant. We are not free to disregard these matters in constructing our theories of law, no matter how innovative we wish them to be.

Tenet (iv) of Indirectly Evaluative Legal Philosophy is also important in the context of transnational legal theory. It claims that legal philosophers should adopt a methodological approach which resists premature and/or immoderate veneration of law, by proceeding from an 'attitude of due wariness' regarding law, and by postponing, and, in a certain sense, limiting, the role of moral evaluation in our theories of law, until certain questions have been addressed.

Indeed, this tenet may be particularly important to hew to in the domain of transnational legal theory. It is, perhaps, all too easy to be bowled over by, and swept up enthusiastically in, the character and pace of certain developments as regards new forms of transnational legality (we might think, for example, of the enthusiasm exhibited by many for developments in international human rights law). However, Tenet

L Farmer, 'Under the Shadow of Parliament House: The Strange Case of Legal Nationalism', both in L Farmer and S Veitch (eds), The State of Scots Law (LexisNexis, 2001).

${ }^{46}$ Case 6/64 Costa v. ENEL [1964] ECR 585 at 593.

47 Joined Cases C-402/05P \& C-415/05P, Kadi and Al Barakaat v Council, [2008] ECR I-6351 para. 282. 
(iv) above counsels against over-hasty moral and other approbation of such developments, and holds that we should seek first to understand, and to analyse the precise character of forms of transnational legality.

This commitment to what we might call 'staged inquiry' is driven by the view is that it will benefit our jurisprudential inquiries, including any moral and political evaluations and criticisms of law we might go on to make, if we first approach law without morally venerating, commending or seeking to justify it. The first stage in our jurisprudential investigations, and our fundamental 'methodological orientation', should see us strive to identify and explain law's important and significant features, without yet taking a stance on whether those features, and the social institution to which they belong, are good or bad. Those features of law so identified and explained may well turn out to be highly relevant to law's later moral and political evaluation and criticism, ${ }^{48}$ but this first stage in the inquiry can and should be conducted without yet engaging in such moral evaluation and criticism.

Why not yet? As I explain more fully elsewhere, ${ }^{49}$ because of a strong commitment to not prematurely venerating law, and not making assumptions from the outset regarding its positive moral value. And why is that commitment so important? Because human history stands obvious and powerful witness to the fact that human beings, and the social institutions they create and administer, have given and continue to give - legal shape to a range of morally repugnant social arrangements and forms of social organization. Moreover, when law and its officials get things wrong and fall into moral and other error, the consequences for us and for our societies are far more serious than when an individual goes thus astray. Law operates on a mass scale, applying itself compulsorily and often coercively to whole population sets at a time. Errors perpetuated by a social institution with this character can be wide-ranging, far-reaching and have significant and sometimes catastrophic effects on the life-chances of those living under it.

We can in fact go further. Not only should transnational legal theory engage in staged inquiry, underpinned by an attitude of due wariness towards its explanandum, but part of its task should be to home in on, alert us to, investigate, and point the way toward the possible amelioration of, the actual and potential flaws, shortcomings, risks and troubling tendencies stemming from the rapid growth of transnational legal and political regulation. An example of a legal philosopher doing just this is to be found in some of Joseph Raz's recent work, and is to be found there notwithstanding the fact that Raz is often cited by theorists in this area as espousing a theory of law which is fundamentally uninterested in, and

\footnotetext{
${ }^{48}$ On this point, see Dickson, Evaluation and Legal Theory (n 6), chapter 7.

${ }^{49}$ See those works referred to in note 6, especially Dickson, 'Ours is a Broad Church: Indirectly Evaluative Legal Philosophy as a Facet of Jurisprudential Inquiry.' $\mathrm{Nb}$ in that article, I note that many legal philosophers strongly reject tenet iv of my approach, and discuss some of their claims in this regard.
} 
incapable of engaging with, anything outside of state law and state legal systems. ${ }^{50}$ In both his lecture entitled 'Sovereignty and Legitimacy: On the Changing Face of Law, Questions and Speculation'51 and in his more recent paper, 'Why the State?'52, Raz engages with some of the challenges of international and transnational legality, and does so proceeding from a theoretical approach which seeks to highlight, alert us to and contribute to the amelioration of, certain problems and risks inherent in some developments in this domain. In 'Sovereignty and Legitimacy', for example, Raz highlights some challenges inherent in the situation where state sovereignty contracts in virtue of contemporary developments in some forms of international law, but this contraction takes place before the international legal community has managed to establish sufficiently strong international institutions to administer the relevant bodies of international law, or managed to ensure sufficient legalization of international relations. One challenge that such a situation brings lies in securing, and demonstrably securing, impartiality and consistency in the operation and application of the bodies of international law in question, including providing credible assurance to all relevant actors that the institutions creating and adjudicating on that law are sufficiently robust to deal even-handedly and without bias with some exceptionally powerful and influential state actors who might appear as litigants in certain cases. Raz's lecture also highlights some problems which may arise from developments in international human rights law, for example, that legal standards perceived as 'alien' by local cultures will be applied to those cultures without sufficient sensitivity to local conditions, and in ways likely to engender conflict and lead to local rejection of the standards concerned. Although on balance welcoming the improvements resulting from aspects of international and transnational legal regulation, Raz's methodological orientation remains appropriately wary and cautious, and allots a central role to highlighting in advance, and attempting to ameliorate step by step as we move forward, problems, challenges and risks emerging from such phenomena. ${ }^{53}$

\section{CONCLUSION}

It is my hope that this article has begun to open up and address some thorny issues regarding the methodology, or the philosophy, of transnational legal theory. The discussion proceeded by identifying and

\footnotetext{
${ }^{50}$ See eg Culver and Giudice, Legality's Borders (n 2), chapter 2; Culver and Giudice, 'Making Old Questions New: Legality, Legal System, and State' (n 2), passim, but especially at 281-5, 290-5.

51 This lecture was delivered orally, and to the best of my knowledge, there is no written version or transcript of it. It was delivered as the Second Kellogg Biennial Lecture on Jurisprudence, and is available to view from: http://blogs.loc.gov/law/2011/10/scholar-joseph-raz-delivers-second-kellogg-biennial-lecture-on-jurisprudence/ . It should be noted that the above represents my personal reconstruction of some aspects of Raz's lecture.

52 J Raz, 'Why the State', unpublished paper available from SSRN at: http://papers.ssrn.com/sol3/papers.cfm?abstract_id=2339522

${ }^{53}$ A similar 'methodological orientation' is evident in Raz, 'Why the State?' (n 52), particularly towards the end of the paper, where Raz considers both the promise and the dangers stemming from developments in certain forms of international law.
} 
exploring some dangers which we must seek to avoid or overcome, and some desiderata towards which we must strive, if our theories of transnational law are to be able successfully to explain and evaluate that domain in all its distinctiveness and complexity. In particular, I have sought to highlight a jurisprudential methodological version of 'not throwing the baby out with the bathwater' as regards making too-hasty assumptions about the degree of novelty exhibited by transnational legal phenomena, and concerning the alleged radical inadequacy of existing jurisprudential concepts and theories in illuminating its character. If we can avoid these dangers, we will be well-equipped in our attempts to develop theoretical understandings of transnational legality exhibiting the desiderata I have discussed here. Such theories should strive to do adequate justice to existing self-understandings of law that shape our lives in important ways, while alerting us to the risks and challenges which developments in transnational legality will inevitably bring. 